\title{
PENGARUH CURRENT RATIO DAN DEBT TO EQUITY RATIO TERHADAP DIVIDEN PAY OUT RATIO YANG BERDAMPAK PADA RETURN ON ASSET PADA PT MANDOM INDONESIA, TBK DI CIBITUNG PERIODE 2010-2020
}

\author{
${ }^{1 *}$ Yulianta, ${ }^{2}$ Veri Muldani, ${ }^{3}$ Nurjaya, ${ }^{4}$ Suratminingsih, ${ }^{5}$ Ana Wijandari \\ 1,2 STIE Hidayatullah, Depok, Jawa Barat, Indonesia \\ ${ }^{3}$ Universitas Suryakancana, Cianjur, Jawa Barat, Indonesia \\ ${ }^{4.5}$ STEBIS Bina Mandiri, Bogor, Jawa Barat, Indonesia \\ *yulianta@stiehidayatullah.ac.id
}

\begin{abstract}
Abstrak
Penelitian ini bertujuan untuk mengetahui pengaruh Current Ratio dan Debt to Equity Ratio terhadap Dividen pay out ratio yang berdampak pada Return on asset pada PT. Mandom Indonesia, Tbk di Cibitung. Metode yang digunakan adalah explanatory research dengan sampel sebnyak laporan keuangan berupa data panel sebanyak 11 tahun. Teknik analisis menggunakan analisis statistik dengan pengujian regresi, korelasi, determinasi dan uji hipotesis. Hasil penelitian ini Current Ratio berpengaruh signifikan terhadap Dividen pay out ratio sebesar 14,0\%, uji hipotesis diperoleh signifikansi $0,047<0,05$. Debt to Equity Ratio berpengaruh signifikan terhadap Dividen pay out ratio sebesar 34,9\%, uji hipotesis diperoleh signifikansi 0,036<0,05. Current Ratio dan Debt to Equity Ratio secara simultan berpengaruh signifikan terhadap Dividen pay out ratio sebesar 39,0\%, uji hipotesis diperoleh signifikansi $0,038<0,05$. Dividen pay out ratio berpengaruh signifikan terhadap Return on asset sebesar 39,8\%, uji hipotesis diperoleh signifikansi 0,038<0,05.
\end{abstract}

Kata Kunci: Current Ratio, Debt To Equity Ratio, Dividen Pay Out Ratio, Return on Asset

\section{Abstract}

This study aims to determine the effect of the Current Ratio and Debt to Equity Ratio on the Dividend payout ratio which has an impact on Return on assets at PT. Mandom Indonesia, Tbk in Cibitung. The method used is explanatory research with a sample of 11 years of financial reports in the form of panel data. The analysis technique uses statistical analysis with regression, correlation, determination and hypothesis testing. The results of this study Current Ratio has a significant effect on the dividend payout ratio of $14.0 \%$, hypothesis testing obtained a significance of $0.047<0.05$. Debt to Equity Ratio has a significant effect on the Dividend payout ratio of $34.9 \%$, hypothesis testing obtained a significance of $0.036<0.05$. Current Ratio and Debt to Equity Ratio simultaneously have a significant effect on the Dividend payout ratio of 39.0\%, hypothesis testing obtained a significance of $0.038<0.05$. Dividend payout ratio has a significant effect on Return on assets of 39.8\%, hypothesis testing obtained a significance of $0.038<0.05$.

Keywords: Current Ratio, Debt To Equity Ratio, Dividend Pay Out Ratio, Return on Assets

\section{PENDAHULUAN}

\section{Latar Belakang}

Perusahaan dapat dinilai dari harga sahamnya. Semakin banyaknya perusahaan yang berdiri di Indonesia, membuat para investor semakin berlomba-lomba menanamkan sahamnya dengan harapan akan memperoleh pengembalian yang baik dari saham yang ditanamnya. Tandelilin (2001) menyatakan bahwa investor yang membeli sejumlah saham saat ini, pada hakikatnya bertujuan untuk mendapatkan dividen (bagian laba setelah pajak yang dibagikan) dan capital gain (selisih dari penjualan saham), sebagai imbalan atas waktu dan risiko yang terkait dengan investasi tersebut. Perusahaan yang baik pasti mampu membagikan dividen. Dividen di suatu perusahaan menjadi pusat perhatian bagi investor, dimana kebijakan tersebut akan menjadikan seorang investor akan membeli, mempertahankan atau memutuskan untuk tidak membeli atau menjual saham yang investor miliki. Dividen berasal dari laba perusahaan. Dividen merupakan arus kas yang disisihkan untuk pemegang saham, sedangkan laba ditahan (retaining earning) merupakan salah satu sumber dana yang paling penting untuk membiayai pertumbuhan perusahaan (Riyanto, 2001). 
Apabila terdapat kelebihan laba setelah digunakan untuk mendanai seluruh kesempatan investasi yang diterima, kelebihan itu akan di distribusikan kepada pemegang saham dalam bentuk dividen kas dan jika perusahaan memiliki proyek investasi dengan pengembalian melebihi yang diminta, perusahaan akan menggunakan laba untuk mendanai proyek tersebut (James C. Van Horne, 2002).

Debt to Equity Ratio (DER) merupakan salah satu faktor yang mempengaruhi dividend payout ratio. Rasio ini mengukur seberapa jauh perusahaan dibiayai oleh hutang, dimana semakin tinggi nilai rasio ini menggambarkan gejala yang kurang baik bagi perusahaan (Sartono 2001). Semakin besar DER (Debt Equity Ratio) menandakan struktur permodalan usaha lebih banyak memanfaatkan hutanghutang relatif terhadap modal. Ketika perusahaan memilih menggunakan hutang sebagai modal untuk investasinya, hutang tersebut harus diperhatikan karena penggunaan utang yang terlalu tinggi akan menyebabkan penurunan dividen sehingga sebagian besar keuntungan dialokasikan sebagai cadangan pelunasan utang. Sebaliknya, pada tingkat penggunaan utang yang rendah perusahaan mengalokasikan

Berikut ini ihtisar data Current Ratio, Debt to Equity Ratio dan Dividen Payout Ratio PT. Mandom Indonesia Periode Tahun 2010-2020

Tabel 1. Current Ratio, Debt to Equity Ratio dan Dividen Payout Ratio PT. Mandom Indonesia Periode Tahun 2010-2020

\begin{tabular}{|c|c|c|c|c|}
\hline Tahun & Current Ratio & Debt to Equity Ratio & Dividen Payout Ratio & Return on Asset \\
\hline 2010 & 892.82 & 13.72 & 65.42 & 1.14 \\
\hline 2011 & 788.63 & 11.68 & 60.22 & 1.22 \\
\hline 2012 & 513.45 & 24.18 & 54.23 & 1.25 \\
\hline 2013 & 674.86 & 24.78 & 46.78 & 1.65 \\
\hline 2014 & 432.91 & 25.72 & 48.91 & 1.13 \\
\hline 2015 & 564.26 & 21.65 & 47.44 & 1.36 \\
\hline 2016 & 672.33 & 19.88 & 38.98 & 1.32 \\
\hline 2017 & 729.96 & 28.68 & 37.36 & 1.38 \\
\hline 2018 & 755.82 & 37.74 & 47.37 & 1.37 \\
\hline 2019 & 585.92 & 26.72 & 36.65 & 1.65 \\
\hline 2020 & 585.95 & 25.43 & 47.57 & 1.35 \\
\hline Rata-rata & 654.26 & 23.65 & 48.27 & 1.35 \\
\hline
\end{tabular}

Sumber: PT. Mandom Indonesia, 2020

Berdasarkan data pada tabel di atas, pencapaian Current Ratio diperoleh rata-rata sebesar $654,26 \%$. Pencapaian dividen yang tinggi sehingga sebagian besar keuntungan digunakan untuk kesejahteraan pemegang saham. Selain itu, hutang yang tinggi juga dapat mendekatkan perusahaan terhadap risiko kebangkrutan (Kartika, 2005).

Namun pada kenyataannya, pada PT. Mandom Indonesia Tbk di Cibitung dari 10 tahun terakhir mengalami perkembangan yang menarik cenderung fluktuasi tingkat DER diikuti dengan tingkat yang juga fluktuasi. Keadaan ini seharusnya tidak terjadi karena semakin tinggi tingkat DER, maka semakin rendah tingkat DPR. Tingginya tingkat DER, dengan semakin tingginya pula tingkat DPR disebabkan karena laba perusahaan menurun, ketika laba menurun, maka kas yang dimiliki perusahaan juga terbatas, namun di sisi lain perusahaan ingin tetap membagikan dividen, sehingga perusahaan melakukan pinjaman yang membuat tingkat utang perusahaan naik. Selain itu, faktor lain yang juga perlu dipertimbangkan dalam besarnya pembagian dividen adalah likuiditas. Likuiditas dihitung dengan menggunakan Current Ratio. Rasio ini digunakan untuk menghitung seberapa mampu perusahaan dalam membayar hutang lancar dengan asset lancar yang dimilikinya. 
48,27\% dan rata-rata Return on Asset sebesar $1,35 \%$.

Perusahaan yang mampu melakukan pembayaran kewajiban jangka pendeknya berarti perusahaan dalam keadaan likuid. Keadaan perusahaan yang mampu membayar jangka pendeknya yang jatuh tempo mengindikasikan bahwa perusahaan mampu juga untuk membayar dividen. Dividen jika dikaitkan dengan likuiditas merupakan arus kas keluar, maka semakin tinggi likuiditas perusahaan berarti makin lancar kemampuannya membayar dividen (Riyanto, 2001).

Return on assets/Rentabilitas menurut Husnan dan Pudjiastuti (2006) adalah "rasio yang mengukur kemampuan perusahaan memperoleh laba operasi perusahaan". Sedangkan menurut Subramanyam dan Will (2008) "laba operasi (operating income) merupakan suatu pengukuran laba perusahaan yang berasal dari aktivitas operasi". Manfaat dari penilaian return on assets selain untuk mendapatkan return juga untuk mengetahui pertumbuhan kinerja perusaan, mengevaluasi kinerja perusahaan dan menentukan kebijakan yang akan datang.

Menurut Toto Prihadi (2010) return on assets dapat dibagi ke dalam tiga kelompok, yaitu Return On Sales (ROS), Return On Equity (ROE), Return on assets (ROA). ROA adalah tingkat return on assets yang dikaitkan dengan penggunaan aset. Rasio ini menunjukkan kemampuan modal yang ditanamkan terhadap keseluruhan aktiva yang dimiliki oleh perusahaan untuk menghasilkan laba. Laba atas aset tersebut adalah perhitungan return on assets perusahaan dengan didasarkan atas net income (laba bersih) dibagi dengan total asset (total aktiva) perusahaan, baik yang diinvestasikan di dalam maupun di luar perusahaan. Menurut hasil penelitian terdahulu yang dilakukan oleh Nita Kripsianti (2013) mengenai Pengaruh Fixed Asset dan Net Working Capital terhadap Profitabilitas dikatakan bahwa "Penggunaan ROA dapat dipakai untuk mengetahui tingkat keuntungan bersih yang diperoleh seluruh modal kerja yang telah diinvestasikan. Semakin tinggi rasio ini semakin baik keadaan perusa

Berdasarkan uraian di atas, maka penulis tertarik melakukan penelitian dengan judul "Pengaruh Current Ratio dan Debt to Equity Ratio Terhadap Dividen Payout Ratio Yang Berdampak Pada Return On Asset Pada PT. Mandom Indonesia Tbk di Cibitung".

\section{Rumusan Masalah}

a. Adakah pengaruh Current Ratio terhadap Dividen pay out ratio pada PT. Mandom Indonesia, Tbk di Cibitung?.

b. Adakah pengaruh Debt to Equity Ratio terhadap Dividen pay out ratio pada PT. Mandom Indonesia, Tbk di Cibitung ?.

c. Adakah pengaruh secara simultan Current Ratio dan Debt to Equity Ratio secara simultan terhadap Dividen pay out ratio pada PT. Mandom Indonesia, Tbk di Cibitung?.

d. Adakah pengaruh Dividen pay out ratio terhadap Return on asset pada PT. Mandom Indonesia, Tbk di Cibitung?.

\section{Tujuan Penelitian}

a. Untuk mengetahui pengaruh Current Ratio terhadap Dividen pay out ratio pada PT. Mandom Indonesia, Tbk di Cibitung .

b. Untuk mengetahui pengaruh Debt to Equity Ratio terhadap Dividen pay out ratio pada PT. Mandom Indonesia, Tbk di Cibitung.

c. Untuk mengetahui pengaruh Current Ratio dan Debt to Equity Ratio secara simultan terhadap Dividen pay out ratio pada PT. Mandom Indonesia, Tbk di Cibitung.

d. Untuk mengetahui pengaruh Dividen pay out ratio terhadap Return on asset pada PT. Mandom Indonesia, Tbk di Cibitung.

\section{TINJAUAN PUSTAKA}

\section{Current Ratio}

Likuiditas menurut Agus Sartono (2009) adalah kemampuan untuk membayar kewajiban financial jangka pendek tepat pada waktunya. Likuiditas 
perusahaan ditunjukan oleh besar kecilnya aktiva lancar yaitu aktiva yang mudah diubah menjadi kas yang meliputi kas, surat berharga, piutang, persediaan. Adapun rumus rasio likuiditas yang digunakan dalam penelitian ini adalah Current Ratio (rasio lancar). Rumus perhitungan CR menurut Irham Fahmi : Current ratio $=$ Current Assets $:$ Current liabilities.

\section{Debt to Equity Ratio}

Hutang menurut Sofyan Syafri Harahap (2011:211) adalah saldo kredit atau jumlah yang harus dipindahkan dari saat tutup buku ke periode tahun berikutnya berdasarkan pencatatan yang sesuai dengan prinsip akuntansi (saldo kredit bukan akibat saldo negative aktiva). Rasio hutang yang digunakan dalam penelitian ini adalah Debt Equity Ratio (Rasio Utang terhadap Ekuitas. Rumus perhitungan DER menurut James $C$ van Horne.

Rasio Utang terhadap Equitas = Total Utang : Ekuitas Pemegang Saham

\section{Dividen Pay Out Ratio}

Dividen menurut Nor Hadi (2013:74) adalah keuntungan yang diberikan pada para pemegang saham yang bersumber dari kemampuan emiten mencetak laba bersih dari operasinya. Rumus yang dipakai dalam menghitung

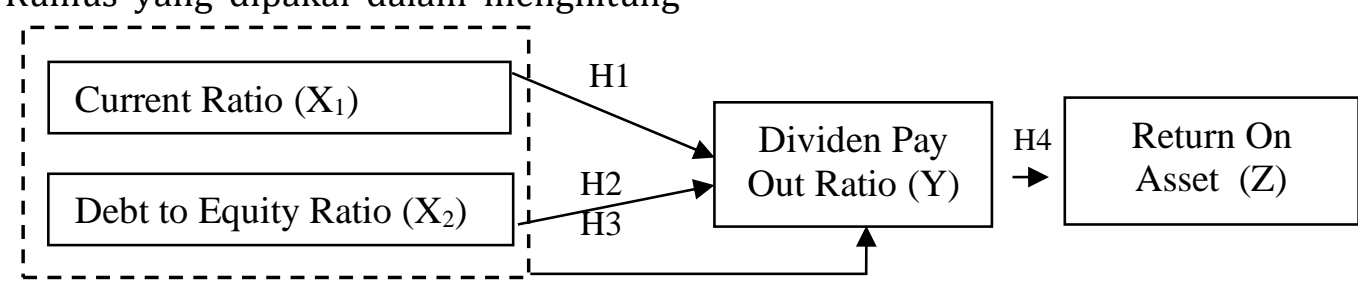

Gambar 1. Paradigma Model Penelitian

\section{Hipotesis Penelitian}

Menurut Sugiyono

"Hipotesis merupakan jawaban sementara terhadap masalah-masalah, karena sifatnya sementara maka perlu dibuktikan kebenarannya melalui data empirik yang terkumpul". Adapun rumusan hipotesis yang diajukan sebagai berikut:

H1 : Terdapat pengaruh yang signifikan Current Ratio terhadap Dividen pay out ratio pada PT. Mandom besarnya dividen yang dibagikan adalah : Dividend Payout Ratio $=$ Dividend

Per Share : Earning Per Share

\section{Return on Asset}

Menurut Kasmir (2016) ROA digunakan untuk menunjukkan kemampuan perus ahaan menghasilkan laba dengan menggunakan total aset yang dimiliki. Return On Asset (ROA) menunjukkan kemampuan perusahaan dalam menghasilkan laba dari aktiva yang digunakan. Return On Asset (ROA) merupakan rasio yang terpenting di antara rasio profitabilitas yang ada. Return On Asset (ROA) atau yang sering disebut juga Reiurn On Investment (ROI) diperoleh dengan cara membandingkan laba bersih setelah pajak terhadap total aktiva (James Van Horne dan John M. Wachowicz,1997)

\section{Model Penelitian}

Menurut pendapat Sugiyono (2018) "Model penelitian merupakan sintesa yang mencerminkan keterkaitan antara variabel yang diteliti dan merupakan tuntunan untuk memecahkan masalah penelitian serta merumuskan hipotesis yang berbentuk bagan alur yang dilengkapi penjelasan kualitatif". Dalam penelitian ini model penelitian yang dibuat sebagai berikut: 
H4: Terdapat pengaruh yang signifikan Dividen pay out ratio terhadap Return on asset pada PT. Mandom Indonesia, Tbk di Cibitung.

\section{METODE PENELITIAN}

\section{Populasi}

Populasi dalam penelitian ini laporan keuangan PT. Mandom Indonesia, Tbk selama 11 tahun yang dibuat dalam bentuk data panel

\section{Sampel}

Teknik pengambilan sampling dalam penelitian ini adalah samplel jenuh, dimana semua anggota populasi dijadikan sebagai sampel. Dengan demikian sampel dalam penelitian ini laporan keuangan selama 11 tahun

\section{Jenis Penelitian}

Jenis penelitian yang dipakai adalah asosiatif, dimana tujuannya adalah untuk mengetahui mencari keterhubungan antara

\section{Teknik Analisis Data}

Dalam menganalisis data digunakan uji asumsi klasik, regresi, koefisien determinasi dan uji hipotesis.

\section{a. Uji Asumsi Klasik}

Uji asumsi klasik dimaksudkan untuk mengetahui ketepatan sebuah data. Dalam penelitian ini uji asumsi klasik yang digunakan adalah meliputi: Uji Normalitas, Uji Multikolinearitas, Uji Autokorelasi, dan Uji Heterokedastisitas. Adapun hasilnya sebagai berikut:

1) Uji Normalitas

Uji normalitas digunakan untuk menguji apakah dalam sebuah model regresi, variabel dependen, variabel independen, atau keduanya mempunyai distribusi normal atau tidak. Uji normilitas menggunakan Kolmogorov-Smirnov test, dengan ketentuan:

(a) Jika nilai signifikansi $<0,05$, maka data tidak berdistribusi normal.

(b) Jika nilai signifikansi > 0,05, maka data berdistribusi normal.

2) Uji Multikolinieritas

Uji Multikolinieritas ini bertujuan menguji apakah pada model regresi ditemukan adanya korelasi antar variabel independen. Dalam penelitian ini digunakan batas tolerance dan lawannya, variance inflation factor (VIF) dengan ketentuan:

(a) Jika nilai nilai tolerance lebih $<1$ dan nilai Variance Inflation Factor (VIF) < dari 1, maka tidak terjadi multikolinieritas.

(b) Jika nilai nilai tolerance lebih $>1$ dan nilai Variance Inflation Factor (VIF) > dari 1, maka terjadi multikolinieritas.

3) Uji Autokorelasi

Uji autokorelasi digunakan untuk mengetahui ada atau tidaknya penyimpangan asumsi klasik autokorelasi, yaitu adanya korelasi antar anggota sampel. Dalam penelitian ini digunakan Durbin Watson Test.

4) Uji Heterskedastisitas

Uji Htereoskaedastisitas bertujuan untuk mengetahui apakah dalam model regresi terjadi ketidaksamaan varian dari suatu residual pengamatan ke pengamatan lain. Cara menprediksi ada atau tidaknya heteroskedastisitas digunakan Glejser Test.

\section{b. Uji Statistik}

1) Regresi Linier

Analisis regresi liner merupakan suatu teknik statistika yang digunakan untuk mencari persamaan regresi yang bermanfaat untuk meramal nilai variabel dependen berdasarkan nilai-nilai variabel independen. Dalam penelitian ini digunakan regresi linier berganda.

2) Koefisien Determinasi Analisis koefisien determinasi dimaksudkan untuk mengetahui besarnya pengaruh antara variabel independen terhadap variabel dependen baik secara parsial maupun simultan.

3) Uji Hipotesis

$$
\text { Pengujian hipotesis }
$$

dimaksudkan untuk menentukan 
apakah suatu hipotesis sebaiknya diterima atau ditolak. Dalam penelitian ini digunakan uji $\mathrm{t}$ (Parsial) dan uji F (Simultan).

\section{HASIL PENELITIAN}

\section{Analisis Deskriptif}

Pada pengujian ini digunakan untuk mengetahui skor minimum dan maksimum skor tertinggi, ratting score dan standar deviasi dari masing-masing variabel. Adapun hasilnya sebagai berikut:

Tabel 2. Hasil Analisis Descriptive Statistics

Descriptive Statistics

N Minimum Maximum Mean Std. Deviation

\begin{tabular}{|l|r|r|r|r|r}
\hline Current Ratio (X1) & 11 & 432.91 & 892.82 & 654.2645 & 133.42484 \\
\hline Debt to Equity Ratio (X2) & 11 & 11.68 & 37.74 & 23.6527 & 7.08776 \\
\hline Dividen pay out ratio (Y) & 11 & 36.65 & 65.42 & 48.2664 & 9.04114 \\
\hline Return on asset (Z) & 11 & 1.13 & 1.65 & 1.3473 & .17367 \\
\hline Valid N (listwise) & 11 & & & & \\
\hline
\end{tabular}

Current Ratio diperoleh varians minimum sebesar $432,91 \%$ dan varians maximum $892,82 \%$ dengan ratting score sebesar $654,26 \%$ dengan standar deviasi 133,42\%.

Debt to Equity Ratio diperoleh varians minimum sebesar $11,68 \%$ dan varians maximum $37,74 \%$ dengan ratting score sebesar $23,65 \%$ dengan standar deviasi 7,08\%.

Dividen pay out ratio diperoleh varians minimum sebesar $36,65 \%$ dan varians maximum $65,42 \%$ dengan ratting score sebesar 48,26\% dengan standar deviasi 9,04\%.

Return on asset diperoleh varians minimum sebesar 1,13\% dan varians maximum 1,65\% dengan ratting score sebesar 1,34\% dengan standar deviasi $0,17 \%$.

\section{Hasil Uji Asumsi Klasik}

a. Uji Normalitas

Hasil uji normalitas dengan alat uji Kolmogorov-Smirnov Test, sebagai berikut:
Tabel 3. Hasil Normalitas KolmogorovSmirnov Test

Tests of Normality

Kolmogorov-

Smirnova $\quad$ Shapiro-Wilk

Stati $\quad$ Statisti

\begin{tabular}{l|l|l|l|l|l} 
stic & df & Sig. & c & df & Sig. \\
\hline
\end{tabular}

\begin{tabular}{l|r|r|r|r|r|r}
\hline Dividen & .199 & 1 & .200 & .922 & 1 & .33 \\
pay out & & 1 & $*$ & & 1 & 7
\end{tabular}

ratio (Y)

*. This is a lower bound of the true significance. a. Lilliefors Significance Correction

Berdasarkan hasil pengujian pada tabel di atas diperoleh nilai signifikansi 0,200 dimana nilai tersebut lebih besar dari nilai $\alpha=$ 0,050 atau $(0,200>0,050)$. Dengan demikian maka asumsi distribusi persamaan pada uji ini adalah normal.

\section{b. Uji Multikonilieritas}

Uji multikolinearitas dilakukan dengan melihat nilai Tolerance Value dan Variance Inflation Factor (VIF). Adapun hasil pengujiannya sebagai berikut:

Tabel 4. Hasil Uji Multikolinieritas dengan Collinierity Statistic.

\begin{tabular}{|c|c|c|c|c|c|}
\hline \multirow[b]{3}{*}{ Model } & \multicolumn{5}{|c|}{ Coefficients $\mathbf{a}^{\mathbf{a}}$} \\
\hline & \multicolumn{2}{|c|}{$\begin{array}{l}\text { Unstandardized } \\
\text { Coefficients }\end{array}$} & \multirow{2}{*}{$\begin{array}{l}\text { Standardized } \\
\text { Coefficients } \\
\text { Beta }\end{array}$} & \multicolumn{2}{|c|}{$\begin{array}{l}\text { Collinearity } \\
\text { Statistics }\end{array}$} \\
\hline & $\mathrm{B}$ & Std. Error & & Tolerance & VIF \\
\hline 1 (Constant) & 54.629 & 17.791 & & & \\
\hline Current Ratio (X1) & .014 & .020 & .214 & .906 & 1.103 \\
\hline Debt to Equity Ratio (X2) & -.670 & .370 & -.525 & .906 & 1.103 \\
\hline
\end{tabular}

a. Dependent Variable: Dividen pay out ratio (Y) 
Berdasarkan hasil pengujian pada tabel di atas nilai tolerance masing-masing variabel bebas yaitu $0,906<1,0$ dan nilai Variance Inflation Factor (VIF) sebesar 1,103 < 10, dengan demikian model regresi ini tidak terjadi multikolinearitas.

\section{c. Uji Autokorelasi}

Pengujian dilakukan dengan alat uji Darbin-Watson ( $D W$ test). Adapun hasil pengujiannya sebagai berikut:

Tabel 5. Hasil Uji Autokorelasi

\section{Model Summary}

\begin{tabular}{lr|r|r|r|r} 
Model & R & R Square & Adjusted R Square & Std. Error of the Estimate & Durbin-Watson \\
\hline 1 & $.624^{\mathrm{a}}$ & .390 & .237 & 7.89497 & 1.926 \\
\hline
\end{tabular}

a. Predictors: (Constant), Debt to Equity Ratio (X2), Current Ratio (X1)

b. Dependent Variable: Dividen pay out ratio (Y)

Hasil pengujian pada tabel di atas diperoleh nilai Durbin-Watson sebesar 1,926 nilai tersebut berada diantara interval $1.550-2.460$. Dengan demikian model regresi dinyatakan tidak ada gangguan autokorelasi.

Tabel 6. Hasil Uji Heteroskesdastisitas dengan Glejser Test Model

\section{Coefficients $^{a}$}

Unstandardized Coefficients Standardized Coefficients

\begin{tabular}{l|r|r|r|r|r} 
Model & B & Std. Error & Beta & t & Sig. \\
\hline 1 (Constant) & -.133 & 9.341 & & -.014 & .989 \\
\hline Current Ratio (X1) & .005 & .010 & .159 & .439 & .672 \\
\hline Debt to Equity Ratio (X2) & .120 & .194 & .223 & .618 & .554 \\
\hline
\end{tabular}

a. Dependent Variable: RES2

Hasil pengujian dengan menggunakan uji glejser diperoleh nilai Sig. $>0,050$. Dengan demikian regression model tidak ada gangguan heteroskesdastisitas.

\section{Analisis Kuantitatif}

Pada analisis ini dimaksudkan untuk mengetahui pengaruh variabel independen terhadap variabel Tabel 7. Hasil Pengujian Regresi Linier Berganda

\section{Coefficients $^{a}$}

Unstandardized Coefficients Standardized Coefficients

\begin{tabular}{l|r|r|r|r|r} 
Model & B & Std. Error & Beta & t & Sig. \\
\hline 1 (Constant) & 54.629 & 17.791 & & 3.071 & .015 \\
\hline Current Ratio (X1) & .014 & .020 & .214 & .737 & .482 \\
\hline Debt to Equity Ratio (X2) & .670 & .370 & .525 & 1.810 & .108 \\
\hline
\end{tabular}

a. Dependent Variable: Dividen pay out ratio (Y)

Berdasarkan hasil pengujian pada tabel di atas, diperoleh persamaan regresi $\mathrm{Y}=54,629+$ $0,014 \mathrm{X} 1+0,670 \mathrm{X} 2 . \quad$ Dari dependen. Adapun hasil pengujian sebagai berikut:

\section{a. Analisis Regresi Linier Berganda}

Uji regresi ini dimaksudkan untuk mengetahui perubahan variabel dependen jika variabel independen mengalami perubahan. Adapun hasil pengujiannya sebagai berikut: 
Debt to Equity Ratio tidak ada, maka telah terdapat nilai Dividen pay out ratio sebesar 54,629 point.

2) Koefisien regresi Current Ratio sebesar 0,014, angka ini positif artinya setiap ada peningkatan Current Ratio sebesar 0,014 point maka Dividen pay out ratio juga akan mengalami peningkatan sebesar 0,014 point.

3) Koefisien regresi Debt to Equity Ratio sebesar 0,670, angka ini positif artinya setiap ada Tabel 8. Hasil Pengujian Koefisien Determinasi Current Ratio Terhadap Dividen

pay out ratio.

Model Summary

\begin{tabular}{cc|c|c|c|} 
Model & R & R Square & Adjusted R Square & Std. Error of the Estimate \\
\hline 1 &
\end{tabular}

\begin{tabular}{|c|c|c|c|c|}
\hline 1 & $74^{a}$ & & .0 & 8.83689 \\
\hline
\end{tabular}

Berdasarkan hasil pengujian diperoleh nilai determinasi sebesar 0,140 artinya Current Ratio memiliki

Tabel 9. Hasil Pengujian Koefisien Determinasi Debt to Equity Ratio Terhadap Dividen pay out ratio.

Model Summary

\begin{tabular}{ll|l|l|l} 
Model & R & R Square & Adjusted R Square & Std. Error of the Estimate \\
\hline
\end{tabular}

\begin{tabular}{lrrrr}
\hline 1 & $.590^{\mathrm{a}}$ & .349 & .276 & 7.69194 \\
\hline a. Predictors: (Constant), Debt to Equity Ratio (X2)
\end{tabular}

Berdasarkan hasil pengujian diperoleh nilai determinasi sebesar 0,349 artinya Debt to Equity Ratio

Tabel 10. Hasil Pengujian Koefisien Determinasi Current Ratio Dan Debt to Equity Ratio Secara Simultan Terhadap Dividen pay out ratio.

Model Summary

\begin{tabular}{lr|l|l|l|} 
Model & R & R Square & Adjusted R Square & Std. Error of the Estimate \\
\hline 1 &
\end{tabular}

\begin{tabular}{|c|c|c|c|c|}
\hline$\overline{1}$ & $.624^{a}$ & .390 & .237 & 7.89497 \\
\hline
\end{tabular}

Berdasarkan hasil pengujian diperoleh nilai determinasi sebesar 0,390 artinya Current Ratio dan Debt to Equity Ratio secera simultan memiliki kontribusi pengaruh sebesar $34,9 \%$ terhadap Dividen pay out ratio.

Tabel 11. Hasil Pengujian Koefisien Determinasi Dividen pay out ratio Terhadap

Return on asset.

Model Summary

\begin{tabular}{ll|l|l|l} 
Model & R & R Square & Adjusted R Square & Std. Error of the Estimate \\
\hline & &
\end{tabular}

\begin{tabular}{lrrrr}
\hline 1 & $.630^{\mathrm{a}}$ & .398 & .331 & .14210 \\
\hline a. Predictors: (Constant), Dividen pay out ratio (Y)
\end{tabular}


Berdasarkan hasil pengujian diperoleh nilai determinasi sebesar 0,398 artinya Dividen pay out ratio memiliki kontribusi pengaruh sebesar 39,8\% terhadap Return on asset.

\section{c. Uji Hipotesis \\ Uji hipotesis Parsial (Uji t)}

Pengujian hipotesis dengan uji t digunakan untuk mengetahui hipotesis parsial mana yang diterima. Adapun hasil pengujian sebagai berikut:

Tabel 12. Hasil Uji Hipotesis Current Ratio Terhadap Dividen pay out ratio.

\section{Coefficients ${ }^{\mathrm{a}}$}

Unstandardized Coefficients Standardized Coefficients

\begin{tabular}{|c|c|c|c|c|c|}
\hline Model & B & Std. Error & Beta & $\mathrm{t}$ & Sig. \\
\hline 1 (Constant) & 31.666 & 13.960 & & 2.268 & .049 \\
\hline Current Ratio (X1) & .025 & .021 & .374 & 2.276 & .047 \\
\hline
\end{tabular}

a. Dependent Variable: Dividen pay out ratio (Y)

Berdasarkan hasil pengujian pada tabel di atas, diperoleh nilai $\mathrm{t}$ hitung $>\mathrm{t}$ tabel atau $(2,276>2,262)$, dengan demikian hipotesis yang Tabel 13. Hasil Uji Hipotesis Debt to Equity Ratio Terhadap Dividen pay out ratio. Coefficients $^{\mathbf{a}}$

\begin{tabular}{|c|c|c|c|c|c|}
\hline \multirow[b]{2}{*}{ Model } & \multicolumn{2}{|c|}{ Unstandardized Coefficients } & \multirow{2}{*}{$\begin{array}{c}\text { Standardized Coefficients } \\
\text { Beta }\end{array}$} & & \multirow[b]{2}{*}{ Sig. } \\
\hline & $\mathrm{B}$ & Std. Error & & & \\
\hline 1 (Constant) & 66.079 & 8.442 & & 7.827 & .000 \\
\hline Debt to Equity Ratio (X2) & .753 & .343 & .590 & 2.294 & .036 \\
\hline
\end{tabular}

a. Dependent Variable: Dividen pay out ratio (Y)

Berdasarkan hasil pengujian pada tabel di atas, diperoleh nilai $\mathrm{t}$ hitung $>\mathrm{t}$ tabel atau $(2,293>2,262)$, dengan demikian hipotesis yang Tabel 14. Hasil Uji Hipotesis Dividen pay out ratio Terhadap Return on asset.

\section{Coefficients ${ }^{\mathrm{a}}$}

Unstandardized Coefficients Standardized Coefficients

\begin{tabular}{lr|r|r|c|c} 
Model & B & Std. Error & Beta & t & Sig. \\
\hline 1 (Constant) & 1.932 & .244 & & 7.928 & .000 \\
\hline Dividen pay out ratio (Y) & .012 & .005 & .630 & 2.437 & .038 \\
\hline
\end{tabular}

a. Dependent Variable: Return on asset (Z)

Berdasarkan hasil pengujian pada tabel di atas, diperoleh nilai $\mathrm{t}$ hitung $>\mathrm{t}$ tabel atau $(2,437>2,262)$, dengan demikian hipotesis yang diajukan bahwa terdapat pengaruh yang signifikan antara Dividen pay out ratio terhadap Return on asset diterima. diajukan bahwa terdapat pengaruh yang signifikan antara Debt to Equity Ratio terhadap Dividen pay out ratio diterima. diajukan bahwa terdapat pengaruh yang signifikan antara Current Ratio terhadap Dividen pay out ratio diterima.

\section{Uji Hipotesis Simultan (Uji F)}

Pengujian hipotesis dengan uji $\mathrm{F}$ digunakan untuk mengetahui hipotesis simultan yang mana yang diterima.

Hipotesis ketiga: Terdapat pengaruh yang signifikan antara Current Ratio, Debt to Equity Ratio dan motivasi terhadap Dividen pay out ratio. 
Tabel 15. Hasil Uji Hipotesis Current Ratio dan Debt to Equity Ratio Secara Simultan Terhadap Dividen pay out ratio.

ANOVA $^{\mathrm{a}}$

\begin{tabular}{llr|r|r|r|r} 
Model & Sum of Squares & df & Mean Square & F & Sig. \\
\hline 1 & Regression & 318.777 & 2 & 159.389 & 4,557 & $.38^{\mathrm{b}}$ \\
\cline { 2 - 7 } & Residual & 498.644 & 8 & 62.331 & & \\
\hline Total & 817.422 & 10 & & & \\
\hline
\end{tabular}

a. Dependent Variable: Dividen pay out ratio (Y)

b. Predictors: (Constant), Debt to Equity Ratio (X2), Current Ratio (X1)

Berdasarkan hasil pengujian pada tabel di atas, diperoleh nilai $\mathrm{F}$ hitung > F tabel atau $(4,557>$ 3,860 ), dengan demikian hipotesis keempat yang diajukan bahwa terdapat pengaruh yang signifikan antara Current Ratio dan Debt to Equity Ratio secara simultan terhadap Dividen pay out ratio diterima.

\section{PEMBAHASAN HASIL PENELITIAN}

\section{Pengaruh Current Ratio Terhadap} Dividen pay out ratio

Current Ratio berpengaruh signifikan terhadap Dividen pay out ratio dengan nilai koefisien determinasi sebesar 14,0\%. Pengujian hipotesis diperoleh nilai $\mathrm{t}$ hitung $>\mathrm{t}$ tabel atau $(2,276>2,262)$. Dengan demikian hipotesis yang diajukan bahwa terdapat berpengaruh signifikan antara Current Ratio terhadap Dividen pay out ratio diterima.

\section{Pengaruh Debt to Equity Ratio} Terhadap Dividen pay out ratio

Debt to Equity Ratio berpengaruh signifikan terhadap Dividen pay out ratio dengan nilai koefisien determinasi sebesar 34,9\%. Pengujian hipotesis diperoleh nilai $\mathrm{t}$ hitung $>\mathrm{t}$ tabel atau $(2,293>2,262)$. Dengan demikian hipotesis yang diajukan bahwa terdapat berpengaruh signifikan antara Debt to Equity Ratio terhadap Dividen pay out ratio diterima.

3. Pengaruh Current Ratio Dan Debt to Equity Ratio Terhadap Dividen pay out ratio

Current Ratio dan Debt to Equity Ratio berpengaruh signifikan terhadap
Dividen pay out ratio dengan diperoleh persamaan regresi $Y=54,629+0,014 X 1$ $+0,670 X 2$, dengan nilai koefisien determinasi sebesar 39,0\% sedangkan sisanya sebesar $61,0 \%$ dipengaruhi faktor lain. Pengujian hipotesis diperoleh nilai $\mathrm{F}$ hitung $>\mathrm{F}$ tabel atau $(4,557>$ 3,860 ). Dengan demikian hipotesis yang diajukan bahwa terdapat berpengaruh signifikan antara Current Ratio dan Debt to Equity Ratio terhadap Dividen pay out ratio diterima.

4. Pengaruh Dividen pay out ratio Terhadap Return on asset

Dividen pay out ratio berpengaruh signifikan terhadap Return on asset dengan nilai koefisien determinasi sebesar 39,8\%. Pengujian hipotesis diperoleh nilai $\mathrm{t}$ hitung $>\mathrm{t}$ tabel atau $(2,437>2,262)$. Dengan demikian hipotesis yang diajukan bahwa terdapat berpengaruh signifikan antara Dividen pay out ratio terhadap Return on asset diterima.

\section{KESIMPULAN DAN SARAN}

\section{Kesimpulan}

a. Current Ratio berpengaruh signifikan terhadap Dividen pay out ratio dengan kontribusi pengaruh sebesar $14,0 \%$. Uji hipotesis diperoleh nilai t hitung > t tabel atau $(2,276>2,262)$.

b. Debt to Equity Ratio berpengaruh signifikan terhadap Dividen pay out ratio dengan kontribusi pengaruh sebesar 34,9\%. Uji hipotesis diperoleh nilai $\mathrm{t}$ hitung $>\mathrm{t}$ tabel atau $(2,293>$ 2,262).

c. Current Ratio dan Debt to Equity Ratio secara simultan berpengaruh signifikan terhadap Dividen pay out ratio dengan kontribusi pengaruh sebesar $39,0 \%$ sedangkan sisanya 
sebesar $61,0 \%$ dipengaruhi faktor lain. Uji hipotesis diperoleh nilai $\mathrm{F}$ hitung > F tabel atau $(4,557>3,860)$.

d. Dividen pay out ratio berpengaruh signifikan terhadap Return on asset dengan kontribusi pengaruh sebesar $39,8 \%$. Uji hipotesis diperoleh nilai $t$ hitung $>\mathrm{t}$ tabel atau $(2,437>2,262)$.

\section{Saran}

a. Current Ratio berpengaruh signifikan terhadap Dividen Payout Ratio dengan Dividen Payout Ratio dengan kontribusi pengaruh sebesar $62,4 \%$ sedangkan sisanya sebesar $37,6 \%$ dipengaruhi faktor lain. Uji hipotesis diperoleh nilai $\mathrm{F}$ hitung $>\mathrm{F}$ tabel atau $(5,281>4,350)$.

d. Kinerja perusahaan dapat memperkuat nilai debt to equity ratio agar nilai equitas meningkat.

\section{DAFTAR PUSTAKA}

Agus Harjito \& Martono, (2010) “Manajemen Keuangan" Yogyakarta: Penerbit Ekonisia.

Algifari. (2015). "Analisis Regresi untuk Bisnis dan Ekonomi". Yogyakarta: BPFE.

Arikunto, Suharsimi (2014). "Prosedur Penelitian Suatu Pendekatan Praktek". Cibitung: Rineka Cipta.

Bambang Riyanto, (2011). "Dasar-dasar Pembelanjaan Perusahaan". Edisi ke empat, BPFE Yogyakarta.

Fahmi, Irham (2012), "Pengantar Manajemen Keuangan" Cetakan pertama. Bandung: Penerbit Alfabeta.

Imam Ghozali (2017). "Aplikasi Analisis Multivariate Dengan Program SPSS". Edisi Kelima. Semarang: Badan Penerbit Undip.

Kasmir (2008), "Analisi Laporan keuangan", penerbit raja grafindo persada, Cibitung.

Kasmir. (2012) "Pengantar Manajemen Keuangan", Edisi Pertama, Cetakan kedua, Cibitung: Prenada Media. kontribusi pengaruh sebesar 2,64\%. Uji hipotesis diperoleh nilai t hitung < t tabel atau $(1,696<2,306)$.

b. Debt to Equity Ratio berpengaruh signifikan terhadap Dividen Payout Ratio dengan kontribusi pengaruh sebesar 44,7\%. Uji hipotesis diperoleh nilai $\mathrm{t}$ hitung $>\mathrm{t}$ tabel atau $(-2,554<$ 2,306).

c. Current Ratio dan Debt to Equity Ratio berpengaruh signifikan terhadap

Kharis, Ismu Fadli (2011). "Studi Mengenai Impulse Buying dalam Penjualan Online". Semarang : Skripsi Universitas Diponegoro

Martono dan Agus Harjito, (2011). "Manajemen Keuangan", Cibitung: Penerbit Ekonisia.

Munawir (2010), "Analisis Laporan Keuangan", Edisi Ke Empat, Penerbit Liberty, Yogyakarta.

Ni Putu Yuria Mendra (2016), "Pengaruh Rasio Keuangan Terhadap Price Earing Ratio Pada Perusahaan Manufaktur yang terdaftar di Bursa Efek Indonesia Tahun 2012-2014" Universitas Mahasaraswati Denpasar,

Rao, Purba, (2012). "Measuring Consumer Perceptions Through Factor Analysis", The Asian.

Santoso, Singgih (2015). "Menguasai Statistik Multivariat". Cibitung: PT Elex Media Komputindo.

Sartono, "Manajemen Keuangan Aplikasi Dan Teori", Edisi Keempat, BPFE, Yogyakarta, 2008.

Sawir, (2003). "Analisis Kinerja Keuangan dan Perencanaan Keuangan Perusahaan", Cetakan ketiga, Cibitung: Penerbit PT. Gramedia Pustaka Utama.

Sudjana (2014) "Metode Statistika", Bandung: Tarsido.

Sugiyarso, G. dan F. Winarni, "Manajemen Keuangan (Pemahaman Laporan Keuangan, Pengelolaan Aktiva, Kewajiban dan Modal. 